\title{
NORMATYWNE PODSTAWY ETYCZNEJ REGULACJI POCZĘĆ
}

\section{STAN ZAGADNIENIA}

Stanowisko Kościoła w nasilającym się od lat międzywojennych sporze na temat etycznej regulacji poczęć jest niedwuznaczne. Wystarczy porównać klasyczne w tej sprawie dokumenty: Casti connubii (1930 r.), Gaudium et spes (1965 r.) oraz Humanae vitae (1968 r.). Chociaż zachodzą między nimi takie czy inne modyfikacje u nauczaniu doktryny katolickiej o małżeństwie i miłości - na pytanie, jakie są dopuśzczalne etycznie środki regulacji poczęć, dają identyczną odpowiedź. Brzmi ona: Jeżeli odpowiednio ważne racje przemawiają za ograniczeniem dzietności, katoliccy małżonkowie mają przed sobą tylko dwie drogi usprawiedliwionego moralnie wyboru. Mogą się zdecydować bądź na całkowite powstrzymanie się od pożycia małżeńskiego, bądź też - korzystając z osiągnięć współczesnych nauk seksuologicznych - na dostosowanie pożycia do cyklicznych okresów niepłodności kobiety, czyli obrać metodę czasowej wstrzemięźli-wości w dniach kobiecej płodności. Inne sposoby zapobiegania ciąży poczynając od mechanicznych i chemicznych środków antykoncepcyjnych, jak również preparatów hormonalnych, a kończąc na przerywaniu ciąży zostały uznane za moralnie naganne, a przeto zakazane.

Ta jasna w swych normatywnych sformułowaniach nauka spotyka się dzisiaj z bardzo szerokim sprzeciwem nie tylko ze strony przedstawicieli chrzecijańskich wyznań niekatolickich (z’a wyjątkiem prawosławia), ale również sporej liczby moralistów katolickich, przede wszystkim w Europie Zachodniej oraz Ameryce Płn. Dyskusja zatoczyła szerokie kręgi. Rozwija się wokół teologicznych aspektów etycznej regulacji poczęć, ale ważną pozycję zajmuje w niej również filozoficzna strona tego zagadnienia. Ta właśnie filozoficzna strona będzie stanowiła właściwy przedmiot niniejszego studium. Zadanie, jakie sobie tu stawiamy, nie polega jednak na tym, aby zbadać, jaką filozofią posługują się papieże w głoszonej 
przez nich nauce o małżeństwie i regulacji poczęć. Tego rodzaju komentarz na temat filozoficznej warstwy nauczania papieskiego $\mathrm{w}$ tej sprawie wydaje się uzasadniony $\mathrm{i}$ atrakcyjny $\mathrm{z}$ teoretycznego punktu widzenia, ale jest to temat dla teologa moralisty. Etyk natomiast - a za takiego uważa się autor obecnego artykułu - musi podejść do zagadnienia od innej strony. Do niego należy naświelić rzecz wyłącznie ze stanowiska filozoficznego, niezależnie od implikacji teologicznych związanych z nauczycielskim magisterium Kościoła, a więc na gruncie rozumowej refleksji, nie zaś wiary. Regulacja poczęć jako określona kategoria ludzkiego działania mieści się bowiem całkowicie w kompetencjach etyki i może, a nawet winna być rozważana przy zastosowaniu filozoficzno-etycznej metody badania.

Ponadto obok wskazanego metodologicznego zacieśnienia tematu (filozofia, a nie teologia) zostanie dokonane jego treściowe ograniczenie. Pod uwagę zostanie wzięta jedynie moralna strona pożycia małżeńskiego w dniach bezpłodnych, ponieważ w życiu katolickich małżenstw nieaprobujących antykoncepcji pożycie to stanowi — praktycznie rzecz biorąc o wiele częściej stosowany sposób regulacji począć, aniżeli całkowita wstrzemięźliwość.

W jakim jednak znaczeniu moralna dopuszczalność tego rodzaju postępowania małżonków urasta do miary problemu etycznego wymagającego osobnej dyskusji i uzasadnienia? Na pierwszy rzut oka mogłoby się wydawać, że jest to rzecz sama przez się zrozumiała. Kiedy ktoś w rozmowie zapytał, co robić, aby dzieci nie było, otrzymał żartobliwą odpowiedź - „nic nie robić”. Czy zaś absolutnie nic, czy też w pewnych granicach, to pozornie problemu nie stwarza. A jednak - poważnie już mówiąc - problem taki stwarza, i to bynajmniej nie prosty! Wstępnych w tym kierunku wyjaśnień dostarcza zapoznanie się $\mathrm{z}$ najważniejszymi przynajmniej zarzutami stawiającymi pod znakiem zapytania moralny charakter pożycia małżeńskiego w dniach bezpłodnych.

\section{PRZEGLĄD ZARZUTÓW}

Nie wydaje się rzeczą celową zajmować się zarzutami, które trącą wýraźną demagogią i do wyjaśnienia sprawy niczego nie wnoszą. Takie wrażenie robią nieudokumentowane opinie o całkowitej zawodności metod naturalnych i przyrównywanie ich $\mathrm{z}$ tego powodu do gry $\mathrm{w}$ ruletkę nazywaną szyderczo przez tych autorów ,rzymską" ${ }^{1}$. Na uważne przestudiowanie zasługują natomiast przede wszystkim trzy argumentacje.

1 "Humanae vitae” und die Freiheit des Gewissens. Materialien zur Auseinandersetzung mit der Enzyklika Papst Paulus VI, Olten und Freiburg im Br. 1968, s. 52 . 


\section{Otwartość aktu na prokreację}

Za punkt wyjścia jednej z nich służy zasada tradycyjnej etyki chrześcijańskiej (głównie w wersji tomistycznej), w myśl której akt małżeński ma za cel prokreację, płodność, wzbudzanie życia. Skoro zaś to ,skierowanie”, ,otwartość" czy ,przeznaczenie” aktu małżeńskiego do zrodzenia nowego życia wyznacza jego podstawową wartość moralną, w takim razie akt spełniany świadomie i dobrowolnie przez małzonków w okresie doraźnej niepłodności kobiety nie odpowiada tej normie, a więc stanowi akt moralnie zły. Zamiast być „otwarty” na prokreację, jest — z racji swej biologicznej struktury - na tę prokreację „,zamknięty”, przeznaczony nie do wzbudzania życia, ale właśnie do jego uniknięcia ${ }^{2}$. Nie zmienia tego stanu rzeczy nawet ewentualne wyjaśnienie ze strony autorów tradycyjnych, że akt małżeński w rzeczywistości niepłodny, mógłby stać się aktem płodnym, gdyby spełniły się wszystkie wymagane po temu warunki biologiczne. Jest to bowiem postulat zgoła nierealny $\mathrm{w}$ odniesieniu do tych aktów, o które nam aktualnie chodzi, a przeto bez znaczenia dla ich moralnej wartości. Małżeński akt bezpłodny faktycznie nie osiąga właściwego celu i osiągnąć go nie może, czyli — zakładając konieczność skierowania go do wzbudzania życia - pozostaje aktem moralnie złym.

\section{Skierowanie intencji ku bezpłodności aktu}

Zarysowaną tu obiekcję pogłębia ^ dodatkowo podbudowuje inna, która polega znowu na uwypukleniu roli intencji, czyli celu zamierzonego za pomocą określonego aktu przez działający podmiot. U podstaw opartej na tej idei argumentacji tkwi założenie, że ta właśnie intencja stanowi istotny wyznacznik moralnej wartości aktu, a więc czynnik pierwszy i podstawowy, wskutek czego inne elementy tejże wartości muszą zejść na drugi plan. Dalszy ciąg rozumowania autorów tego zarzutu zmierza do wykazania, że w akcie małżeńskim okresowo bezpłodnym intencja małżonków zwraca się zawsze i zwracać musi ku bezpłodności tego aktu. Po to się bowiem ustala czas pożycia małżeńskiego na dni bezpłodne, aby uniknąć potomstwa. To nastawienie małżonków nie ulega zmianie nawet wtedy, kiedy akt mał̇żenski ma służyć pogłębieniu miłości i duchowej wspólnoty małżeństwa. Fundamentalna intencja wyeliminowania prokreatywnych skutków pożycia małżeńskiego - zakładając dominującą rolę tej intencji w konstytuowaniu moralności aktu ludzkiego - stawia to pożycie w opozycji do jego monalnego, na prokreację ukierunkowanego przeznaczenia, co przesądza o jego niemoralnym charakterze ${ }^{3}$.

2 J. Gründel, Fragen an den Moraltheologen, München 1969, s. 116; B. Schüller, Die Begründung sittlicher Urteile. Typen ethischer Argumentation in der katholischen Moraltheologie, Düsseldorf 1973, s. 166; B. Häring, Krise um „Humanae vitae”, Bergen-Enkheim bei Frankfurt am Main 1968, s. 53-54.

3 Gründel, jw., s. 116. 


\section{Biologizm tradycyjnej etyki małżeńskiej}

Mimo wszystko trudność przedstawiona w powyższym wywodzie odgrywa w dyskusji nad moralną dopuszczalnością pożycia małżeńskiego w dniach bezpłodnych raczej drugorzędną rolę. O wiele bardziej zasadnicze zastrzeżenia budzi inny element doktryny tradycyjnej. Chodzi tu o zależność, jaką w mniemaniu przeciwników doktryna ta przyjmuje między biologicznymi prawami ludzkiej płciowości a moralnymi normami obowiązującymi w zakresie tejże płciowości. Zastrzeżenia te - zdaniem podtrzymujących je autorów - szczególnie dobitne potwierdzenie swej słuszności znajdują właśnie w sprawie usprawiedliwienia moralnego pożycia małżeńskiego w okresie dni bezpłodnych. Dowodzą zaś tego w ten sposób. Najpierw stawiają pytanie, jaka jest ostateczna racja, w imię której etyka tradycyjna mówi bezwzględnie „nie” na stosowanie jakichkolwiek środków antykoncepcyjnych, wyrozumiałe zaś ,tak" na pożycie w okresie czasowej (tym bardziej trwałej, patologicznej) bezpłodności. Odpowiedź na to pytanie widzą $\mathrm{w}$ determinizmie biologicznych praw, którym poddany jest ludzki organizm odpowiednio do jego płciowego zróżnicowania. Doktryna tradycyjna patrzy na występujące tu struktury biologiczne i procesy, jako na coś sakralnego i nietykalnego. W imię tej właśnie nietykalności zakazuje w sposób absolutny ingerować w prawidłowy przebieg tych procesów przy pomocy środków antykoncepcyjnych, a równocześnie na tej samej podstawie pozwala (pod pewnymi warunkami) korzystać z zawartej $\mathrm{w}$ ich biologicznej rytmice szansy bezpłodności. A tymczasem - i tu autorzy zarzutu przystępują do zdarcia maski $\mathbf{z}$ fundamentalnego błędu doktryny tradycyjnej - w zarysowanym rozumowaniu ma miejsce widoczne, ale logicznie zupełnie nieuprawomocnione przejście od absolutnego determinizmu praw biologicznych do absolutnie obowiązujących praw moralnych. Pierwsze są dziełem woli Boga Stwórcy i Praprzyczyny wszechrzeczy, podczas gdy drugie pochodzą od woli Boga Prawodawcy i Gwaranta porządku moralnego. A zatem rzecz się rozgrywa na dwu odrębnych i zgoła odmiennych płaszczyznach rzeczywistości, na jednej rządzi fizyczna konieczność, druga poddana jest ostatecznie prawu wolności i kierowniczej roli rozumu ludzkiego. Doktryna tradycyjna nie dostrzega tych różnic przynajmniej w tym stopniu, w jakim usiłuje dostosować moralność seksualnych zachowań człowieka do nieugiętej regularności mechanizmów biologicznych zarówno wtedy, kiedy każe szanować ich prokreatywne uzdolnienia, jak też kiedy godzi się na unikanie potomstwa $\mathrm{w}$ granicach organicznej bezpłodności. Ale tym samym daje dowód, że tkwi w przestarzałych poglądach na naturę ludzkiej płciowości i raczej gotowa jest poświęcić człowieka na rzecz etycznego biologizmu i fizycyzmu, aniżeli skorzystać z osiągnięć nowșej an- 
tropologii $\mathrm{i}$ otworzyć w moralności wrota dla ludzkiego rozumu. Nic więc dziwnego, że nie przemawia do przekonania współczesnego człowieka zatroskanego o dobro osoby, a nie aktu, stawiającego pomyślność małżeństwa czy zbawienie człowieka wyżej, aniżeli nienaruszalność biologicznych procesów ${ }^{4}$.

Propozycja przeciwników doktryny tradycyjnej zmierza więc do tego, aby spojrzeć na człowieka i jego płciowość nie poprzez pryzmat biologicznych determinacji, ale psychofizycznej jedności jego natury. Pozwoli to ująć moralność małżeństwa, przede wszystkim zaś problem regulacji poczęć, w świetle tzw. zasady totalności. Monalność stosowanych metod ustala się tu na podstawie ich odniesienia do całościowo widzianych prokréatywnych i indywidualnych celów małżeństwa, nie zaś wewnętrznej struktury poszczególnych aktów. W tej perspektywie znika stała i nieprzekraczalna granica między metodami sztucznymi (antykoncepcją) a naturalnymi (okresowa wstrzemięźliwość). Obie stać się mogą godziwe lub niegodziwe w zależności od tego, czy wolna decyzja małżonków pójdzie po linii ustalonych przez nich samych postulatów odpowiedzialnego rodzicielstwa (wtedy będzie usprawiedliwiona), czy też hedonistycznego egoizmu (co będzie oznaczać jej moralne potępienie).

\section{OGOLNA CHARAKTERYSTYKA OMOWIONYCH ZARZUTOW}

Jak wynika $\mathrm{z}$ dotychczasowych wywodów, kontestacja tradycyjnej doktryny na temat moralnej godziwości pożycia małżeńskiego w okresach cyklicznej bezpłodności kobiety da się sprowadzić ostatecznie do dwu punktów. Stwierdza się więc wbrew tej doktrynie, że pożycie małżeńskie $\mathrm{w}$ dniach bezpłodnych jest moralnie złe i niedopuszczalne, ponadto osą-dza się jako błędną zasadę przypisywaną tejże doktrynie, że metody regulacji poczęć winny pozostawać w zgodzie z biologiczną strukturą i funkcjonowaniem ludzkiej płciowości.

Pamiętać wszakże należy, że autorzy dowodzący wbrew doktrynie tradycyjnej moralnego zła pożycia małżeńskiego w okresach biologicznej bezpłodności, nie czynią tego $\mathrm{w}$ przekonaniu, jakoby ten akt rzeczywiście uważali za moralnie zły. W gruncie rzeczy chodzi im o coś zupełnie innego. Chcą oni mianowicie wykazać, że doktryna tradyeyjna jest wewnętrznie sprzeczna. Jeżeli bowiem doktryna ta przyjmuje, że akt małżeński $\mathrm{z}$ natury zmierza do zrodzenia potomstwa, $\mathrm{w}$ takim razie winna potępić moralnie wszelkie pożycie małżeńskie, w którym nie może dojść do zawiązania się życia. Tak zaś dzieje się nie tylko w wypadku stosowania środków antykoncepcyjnych, ale także wykorzystywania biologicz-

4 Schüller, jw., s. 170-174; Häring jw., s. '55-56; Fr. Böckle, L'Église et la sexualité. Pour une morale dynamique, „Concilium” 100 (1975) s. 140-142. 
nej bezpłodności dla celów antyprokreatywnych. Tymazasem dokitryna tradycyjna zamiast wyciągnąc z idei prokreatywnego ukierunkowania aktu obydwie te konsekwencje, ogranicza się tylko do jednej: potępia antykoncepcję, aprobuje zaś pożycie bezpłodne. Wskutek tego popada w niekonsekwencję.

A zatem $\mathrm{w}$ momencie, w którym doktryna tradycyjna odstąpiłaby od moralnego potępienia środków antykoncepcyjnych, jej oponenci nie mieliby nic przeciwko temu, aby uznać dopuszczalność czasowej wstrzemięźliwości na równi z innymi metodami regulacji poczęć (za wyjątkiem przerywania ciąży oraz śnodków uniemożliwiających zagnieżdżenie się zapłodnionego jajeczka względnie usuwających z macicy zagnieżdzone już jajeczko). Punkt ciężkiości toczącego się sporu między dokstryną tradycyjną a jej katolickimi kontestatorami spoczywa zatem po stronie zakazu środków antykoncepcyjnych. Sprawa moralnego charakteru bezpłodnych aktów małżeńskich jest tylko pochodną tego zakazu. A.by obronić antykoncepcję, atakuje się moralność małżeńskich aktów bezpłodnych. Czyni się to na zasadzie argumentacji ,reductio ad absurdum".

Mimo wszystko w mniemaniu przeciwników doktryny tradycyjnej ni braki w logicznej konsekwencji rozstrzygają o jej teoretycznej sła abości. Właściwe źródła tej słabości kryją się w założeniach metodologicznych, na których opiera się doktryna tradycyjna. Idzie o to, że cała moralność seksualna, w jej zaś ramach moralność małżeńska i problem regulacji poczęć opierają się na fundamencie biologicznej zasady, która prawidłowość i nieugiętość struktur i procesów płciowych uznaje za siłę sprawczą norm moralnych obowiązujących w tej sfẹrze ludzkich zachowań. A to oznacza skrzywienie fundamentalnej optyki całej filozofii moralności, związanie jej z fałszywą wizją człowieka i jego działania. Tradycyjna doktryna moralna domaga się zatem gruntownej przebudowy na wszystkich, poziomach swej teoretycznej struktury.

Można zatem wmiloskolwać, że sam rdzeń i sedno problemu moralnej dopuszczalności okresowej wstrzemięźliwości małżeńskiej, a równocześnie klucz do jego rozwiązania kryje się niejako na zewnątrz tego problemu, $\mathrm{w}$ zagadnieniach związanych $\mathrm{z}$ nim, lecz co do treściowej zawartości odrębnych. Bezpośrednio sięga korzeniami zakazu antykocepcji, pośrednio, ale za to prycypialnie, powiązań zachodzących między normatywnymi podstawami małżeńskich zachowań seksualnych a biologicznym podłożem płciowości. Oczywiście zagadnienie moralnych aspektów pożycia małżeńskiego w okresach bezpłodności wnosi w dyskusję również własne wątki teoretycznè. Mimo to punkt ciężkości i kluczowe elementy jego rozwiązania sięgają najgłębszej warstwy właściwych mu teoretycznych założeń i przesłanek. W tym przeto kierunku zwrócić się muszą dalsze dociekania. 
IV. NORMATYWNE PODSTAWY REGULACJI POCZEC ZA POMOCĄ METODY OKRESOWEJ WSTRZEMIĘŹLIWOSCI

\section{Zasada wewnętrznej określoności aktu ludzkiego}

W normatywnych rozważaniach współczesnych autorów na temat regulacji poczęć występuje często opozycja dwu stanowisk: „,nowszej” antropologii aprobującej antykoncepcję jako osiągnięcie rozumu i wolności oraz etyki tradycyjnej negującej antykoncepcję w imię kultu natury i sztywnego rygoru ${ }^{5}$.

Otóż bez ogródek należy stwierdzić, że powyższe przeeciwstawienia w podanym ogólnikowym sformułowaniu stanowią tylko stylistyczną ornamentykę, swego rodzaju etykietę naklejoną na zgoła inną treść, jaka się poza nimi ukrywa. W gruncie rzeczy chodzi tu o alternatywne rozstrzygnięcie podstawowego problemu etyki filozoficznej, $\mathrm{z}$ jakich źródeł akt ludzki w ogóle, w naszym zaś wypadku akt małżeński, czerpie wyznaczniki swej moralnej wartości, innymi słowy: skąd biorą się czynniki, które mają decydujące znaczenie dla określenia, czy akt ludzki jest moralnie dobry, zły, względnie obojętny. A skoro tak się rzeczy mają, wobec tego dla celowego i obiekikiwnego ustawienia dyskusji nad moralnością metod regulacji poczęć jest rzeczą konieczną, aby było wiadomo, jak się przedstáwia w tej sprawie autentyczny sens poglądów obu dyskutujących stron zarówno ná poziomie ogólnoetycznego rozstrzygnięcia, jak też w zastosowaniu do szczegółowego zagadnienia moralnej dopuszczalności bezpłodnych aktów małżeńskich. Analiza wypowiedzi współczesnych przeciwników doktryny tradycyjnej na ten temat pokazuje, że nie dają one w pełni zadowalającego obrazu poglądów na całość zagadnienia.

Jeżeli chodzi o ich własne stanowisko, zauważa się brak wyraźnego i jednoznaicznego określenia, jakką koncepcję źródeł moralności aktu przyjmują za punkt swoich normatywnych ustalen. Zazwyczaj postępują w ten sposób, że zakładając milcząco określoną koncepcję'w tej sprawie, podają od razu własny pogląd na źródła moralności aktu małżeńskiego, który. sformułowany jest zgodnie z tą milcząco przyjętą koncepcją. Decydującą rolę $\mathrm{w}$ ich ujęciu pełnią globalnie wzięte skutki pożycia małżeńskiego w ich relacji do określonych interesów małżeństwa, względnie subiektywne cele świadomie przez małżonków stawiane w zakresie ich pożycia małżeńskiego. Ponieważ wszystkie te czynniki (skutki i cele) są zmienne i zależne od sytuacyjnych układów pożycia małżeńskiego, wskutek tego oparte

${ }^{5}$ Fr. Scholz, Wege, Umwage und Auswege der Moraltheologie. Ein Plädoyer für begründete Ausnahmen, München 1976, s. 141; „Humanae vitae” und die Freiheit des Gewissens, S, 30-33; J. Rock, Geburtenkontrolle. Vorschläge eines katholischen Arztes, Olten und Freiburg im Br. 1964, s. 47-48. 
na nich normy postępowania mają również charakter norm relatywnych i dopuszczają odpowiednie wyjątki. Do takich wyjątków usprawiedliwionych ze względu na odpowiednie sytuacje i cele małżeńskie należą przypadki, w których małżonkowie uznają za konieczne stosowanie środków antykoncepcyjnych czy też (ewentualnie) pożycie w dniach bezpłodnych. To właśnie rozwiązanie zwie się etyką rozumu i wolnych rozstrzygnięć.

Referując z kolei doktrynę tradycyjną przypisują jej pogląd, w myśl którego źródła moralności aktu małżeńskiego zasadzają się na biologicznej prawidłowości jego struktury i funkcjonowania. Prawidłowość ta stanowi niewątpliwie kategorię stałą i w podstawowych swych elementach wykazuje jednoznacznie określoną regularność. Etyka tradycyjna opierając się na tych założeniach, formułuje niezmienne i bezwyjątkowe normy postępowania w sferze życia seksualnego, czego logiczną konsekwencją jest potępienie środków antykoncepcyjnych, ale już niekonsekwencją - aprobata pożycia małżeńskiego $\mathrm{w}$ dniach bezpłodnych. To stanowisko określa się znowu mianem etyki natury i rygorystycznego biologizmu.

W rzeczywistości sprawa jest jednak bardziej skomplikowana. Co prawda, w dyskusji nad moralnością pożycia małżeńskiego w okresie bezpłodności nie ma miejsca na obszerniejszą analizę fundamentalnych aspektów źródeł moralności aktów ludzkich i uzasadnienie zajętego stanowiska. Mimo wszystko ogólnie orientujące wyjaśnienia w tej sprawie wydają się konieczne, aby uwyraźnić to, co w wywodach przeciwników doktryny tradycyjnej zostało przemilczane, względnie skorygować to, co zostało przeinaczone.

Z historii etyki wiadomo, że na pytanie, skąd akt ludzki czerpie pierwsze wyznaczniki swej moralnej wartości, filozofia moralności daje (zasadniczo rzecz biorąc) dwie odpowiedzi. Jedna z nich stwierdza, że wyznaczniki te znajdują się ,na zewnątrz” aktu. Akt ludzki „,od wewnątrz”, ,sam w sobie" jest nieokreślony, otwarty jednakowo na dobro i zło moralne. Wartości moralnej nabiera w zależności bądź od celów zamierzonych przez podmiot (subiektywizm etyczny), bądź od oszacowania globalnej sumy realizowanych skutków w postaci stanów przyjemnościowych (utylitaryzm naturalistyczny, hedonizm), albo też dóbr osobowych (teleologizm), bądź też ad całokształtu okoliczności domagających się odpowiednich kompromisów etycznych na zasadzie wybierania zła mniejszego (sytuacjonizm etyczny). W poszczególnych wersjach tego stanowiska wskazuje się przeto na rozmaite, choć często powiązane ze sobą źródła moralności. Mimo to wszystkie te wersje łączy $\mathrm{w}$ jedną filozoficznoetyczną orientację podstawowa teza stwierdzająca wewnętrzną nieokreśloność i plastyczność moralną aktu ludzkiego, w następstwie czego z konieczności okazuje się on podatny na zmienne układy determinujących go moralnie czynników. Ta wspólnota podstawowej tezy. wraz z zawartą w niej implikacją, że 
wartość moralna aktu ludzkiego może ulegać zmianie i dopuszcza odpowiednie wyjątki na wskazanych uprzednio zasadach (cele, oszacowanie dóbr, kompromis), sprawia, że stanowisko to nosi w filozofii moralności nazwę „relatywizmu etycznego".

Przeciwstawną do omówionej pozycję filozoficznoetyczną zajmuje kie-runek, który wychodzi z założenia, że akt ludzki już we wnętrzu własnej dynamicznej natury, czyli ,sam w sobie” zawiera podstawowe czynniki właściwej mu moralnej określoności. Czynniki te utożsamia się z podstawową zasadą strukturalną charakteryzującej go celowości, która polega na skierowaniu aktu, inaczej: na przeznaczeniu go do urzeczywistnienia odpowiedniego skutku uznanego za pierwszy i rozstrzygający dla określenia wewnętrznej specyfiki tego aktu. Nie wszystkie bowiem skutki działania, jak też nie wszystkie składniki sytuacji, w której podmiot działa, są jednakowo ważne dla ukonstytuowania celowości określającej akt moralnie. Na czoło wysuwa się jeden, pórządkujący akt od wewnątrz, jako punkt odniesienia i umiejscowienia w strukturze aktu pozostałych jego składników. Nosi on nazwę ,,przedmiotu aktu”, jego „,materię", względnie „cel czynności” (finis operis). Rola tego skutku polega przede wszystkim na tym, że jest on siłą twórczą wewnętrznej organizazacji i tożsamości aktu.

Nakreślona tu filozoficzna perspektywa aktu ludzkiego upatruje istotne elementy jego dynamicznej struktury w znamionującym ten akt u p o$\mathrm{rza} d \mathrm{kow}$ aniu i organizacji jego składowych elementów. Mocą tego uporządkowania zostaje akt od wewnątrz skierowany do urzeczywistnienia specyfikującego go skutku (przedmiotu, celu czynności). I nie co innego, ale właśnie to ukierunkowanie, to celowe zwrócenie aktu mocą istotowej struktury w stronę danego skutku określa właściwą temu aktowi dynamiczną rzeczywistość, za czym dopiero idzie jego faktyczne urzeczywistnienie.

Wyeksponowanie naczelnej roli celu czynności w konstytuowaniu wewnętrznej swoistości aktu nie przekreśla jednak tej możliwości, że akt ludzki potrafi spowodować obok celu czynności jeszcze inne skutki. Ta „wielocelowościowość" (Mehrzwecklichkeit ${ }^{6}$ ) aktu stawia co prawda przed refleksją filozoficznoetyczną zadanie, który z wielu skutków aktu jest jego celem czynności, ale spełnienia tego zadania bynajmniej nie udaremnia. Nie mogąc rozwinąć szerzej tej myśli, trzeba się ograniczyć do krótkiego stwierdzenia, że najbardziej odpowiednią do tego metodą jest należycie przeprowadzona analiza struktury odnośnego aktu.

Ważne natomiast jest to, że zakotwiczenie moralności aktu ludzkiego w jego przedmiocie, czyli celu czynności decyduje w sposób jednoznaczny

${ }^{6}$ Schüller, jw., s. 166. 
o jego moralnej określoności. W grę wchodzą trzy możliwości: $1^{\circ}$, cel czynności pozostaje w stałym związku z odpowiednim dobrem (wartością) moralnym; $2^{\circ}$, cel czynności okazuje się równie stale niezgodny z tym dobrem; $3^{\circ}$, tenże cel nie ma żadnego stałego związku z określonym dobrem moralnym. W pierwszym wypadku akt jest wewnętrznie i niezmiennie dobry, w drugim akt $\mathrm{z}$ konieczności przybiera cechę wewnętrznego zła, natomiast $w$ ostatnim wypadku akt pozostaje wewnętrznie nieokreślony, czyli „moralnie obojętny”, podatny na różne, a przeto zmienne układy czynnikỏw zewnętrznych w postaci subiektywnych celów podmiotu działającego czy innych okoliczności. Opierając się na tych założeniach można przyjąć, że dwie pierwsze ewentualności (stała zgodność, względnie stała niezgodność celu czynności z dobrem moralnym) stwarzają podstawę do twierdzenia, że określone kategorie aktów ludzkich mają moralną określoność wewnętrzną i stałą, dobrą lub złą, ale pozostającą taką we wszystkich warunkach niezalężnie od dalszych skutków, subiektywnych celów czy innych układów sytuacyjnych. Ta kwalifikacja moralna w wypadku, kiedy chodzi o akt wewnętrznie ziy (akt wewnętrznie dobry podlega innej prawidłowości), przekreśla ewentualne wyjątki od zasadniczego pionu moralnego aktu $\mathrm{w}$ zależności od zmieniających się okoliczności, w których podmiotowi przychodzi działać, stawia twardą i nieugiętą regułę: akt wewnętrznie zły nigdy nie może stać się moralnie usprawiedliwiony i dopuszczalny, innymi słowy, wyklucza możliwość stosowania w zakresie tego aktu zasady moralnych wyjątków i kompromisów. Widać wszakże, że ta nieugiętość jest prostą konsekwencją dominującej pozycji, jaką w koncepcji tradycyjnej zajmuje idea wewnętrznej i stałej kwalifikacji moralnej odpowiedniej kategorii aktów ludzkich. Z uwagi na to koncepcja ta $\mathrm{w}$ przeciwstawieniu do relatywizmu etycznego $\mathrm{w}$ historii etyki otrzymała nazwę ,etyki absoluthej”, względnie ,absolutyzmu etycznego".

W świetle dotychczasowych ustaleń (a właściwie tylko przypomnień) mimo ich wstępnego charakteru można jednak dokonać krytycznej oceny pierwszego ze zreferowanych zarzutów skierowanych przeciwko idei „otwartości”, inaczej „przeznaczenia” aktu małżenskiego do realizacji prokreatywnych celów małżeństwa. Nie trudno wykazać, że przyjęta w założeniach tego zarzutu interpretacja wspomnianej „otwartości”, aktu opiera się na znacznym uproszczeniu i wykrzywieniu właściwej treści tego pojęcià. Utożsamiono ją bowiem z faktyczną prokreatywną efektywnością áktu małżeńskiego i z tego tytułu akt małżeński w okresie biologicznej bezpłodności uznano za „zamknięty” na rodzicielstwo. Ten swoisty efektywizm etyczny $w$ gruncie rzeczy stanowi tylko filozoficzne echo utylitarystycznego i pragmatycznego stylu myślenia etycznego wypracowanego głównie na terenie brytyjskiego naturalizmu. Miarę moralności alktu ludzkiego przerzuca on w sferę zewnętrznego działania człowieka i zakłada ją 
na przewidywanych skutkach tego działania w samym podmiocie i społeczeństwie. Jednakże jednostronność tego kryterium powoduje, że użyty jako narządzie krytyki doktryny tradycyjnej nie daje pożądanych rezultatów.

Koncepcja tradycyjna prokreatywną otwartość (przeznaczenie) aktu małżeńskiego umieszcza na płaszczyźnie dynamicznej struktury celowościowej, specyfikującej moralnie każdy akt ludzki. Dotyczy ona zatem innego, aniżeli w efektywizmie aspektu aktu małżeńskiego, pod względem strukturalnym wcześniejszego od jego efektywności. Wyraża bowiem tę rzeczywistość aktu małżeńskiego, która utożsamia się $\mathrm{z}$ jego wewnętrznym uporządkowaniem i organizacją. Dzięki temu znajduje on we własnym wnętrzu zasadę działania po linii tkwiącej w nim prawidłowości. Prawidłowość ta zawiera $\mathrm{w}$ sobie skierowanie aktu do określonego skutku, ponieważ sama została ukonstytuowana poprzez odniesienie do tego skutku. Z drugiej jednak strony zachowuje ona właściwą sobie specyfikę w każdym założeniu, czy skutek został efektywnie sprawiony, czy' też nie. $\mathrm{Na}$ tym polega otwartość aktu małżeńskiego w myśl teorii tradycyjnej. Jeżeli tylko został dokonany zgodnie z odpowiadającą mu celowością, pozostaje aktem „otwartym" zarówno wtedy, kiedy osiągnął właściwy sobie skutek, jak i wtedy, kiedy został spełniony, ale odpowiadającego mu skutku nie spowodował. Niepotrzebne okazują się zatem ewentualne korektury, że niepłodny akt małżeński mógłby być otwarty na płodność, gdyby zaistniały potrzebne po temu warunki biologiczne. Nawet nieefektywny co płodności akt małżeński jest otwarty na płodność, jeżeli został do-konany zgodnie $\mathrm{z}$ określającą go od wewnątrz celowością. To zdawałoby się nieznaczne przesunięcie akcentów w interpretacji otwartości aktu na prokreację zawiera jednak w sobie zalążki poważnych konsekwencji teoretycznych, których właściwy ciężar gatunkowy ujawnia się dopiero nä dalszych etapach naszych rozważań.

\section{Osobowy charakter wewnętrznego finalizmu aktu małźeńskiego}

\section{a) Przypomnienie obiekcji}

Wyeksponowanie wewnętrznego uporządkowania i przeznaczenia aktu małżeńskiego jako preefektywnego jego aspektu uchyla - jak się zdaje - jednostronność pierwszego zarzutu wysuniętego pod adresem tradycyjnej etyki małżeńskiej, ale wzmacnia za to pozycję drugiego. Koncentruje się on bowiem na tej właśnie preefektywnej stronie aktu ludzkiego, aby ukazać tu właśnie ukrýte źródła bezwzględnego zakazu stosowania środków antykoncepcyjnych głoszonego przez etykę tradycyjną. Jak wiadomo, źródła te upatrują oponenci w determinizmie praw rządzą- 
cych biologiczną strukturą i funkcjonowaniem płciowości. Nieodwracalność i konieczność tych praw wyrażona dogmatycznie a naiwnie w normatywnym języku tradycyjnej filozofii daje w wyniku absolutny zakaz ingerowania $\mathrm{w}$ te prawidłowości za pomocą środków antykoncepcyjnych jakiegokolwiek rodzaju. Tak przedstawia się sens tradycyjnej etyki małżeńskiej w interpretacji jej współczesnych przeciwników, a jak wygląda ten sens w rzeczywistości?

b) Płodność i niepłodność jako integralne składniki struktury i funkcjonowania ptciowości

Aby naświetlić istotny sens doktryny tradycyjnej, trzeba dokonać podwójnej korektury. w wywodach jej oponentów. Niewątpliwie w określaniu obiektywnych i niezmiennych (absolutnych) podstaw moralności aktu małżeńskiego punkt wyjścia i jakoby dolną warstwę wchodzących w grę czynników stanowi biologiczna struktura i uwarunkowane przez nią funkcjonowanie ludzkiej płciowości. Jak dotąd nie ma podstaw do wszczynania sporu. Jednakowoż doktryna tradycyjna akceptując tę strukturę, jako fundamentalny element moralności aktu, wskazuje równocześnie na dwa obiektywne wymiary tego aktu, które w istotny sposób rzutują na kształtującą się na tym gruncie jego moralność.

Przede wszystkim należy patrzeć na ludzką płciowość w sposób integralny. Znaczy to, że celowość aktu małżeńskiego jest konstytuowana przez całokształt biologicznych składników i procesów płciowości, a więc zarówno przez te, które determinują biologiczną płodność aktu małżeńskiego, jakk też i przez te, które warunkują jego niepłodność. To są dwa integralne pierwiastki określające całościowo wziętą prokreatywność aktu. Struktura ludzkiej płciowości jest taka, że dla spełnienia swych zadań wymaga ona zarówno stanów płodności, jak też bezpłodności, które zresztą w swej zasadniczej treści nie są zaprzeczeniem płodności, ale jej przygotowaniem i zdynamizowaniem. Stanowi ona przeto kategorię nadrzędną, powstałą jako swoista jedność i wzajemne dopełnienie płodności i niepłodności, podobnie jak kategoria życia rośliny obejmuje zarówno czas wegetacji wiosennej jak i zimowego zamierania.

Tak przedstawia celowość płciowości rozumianej jako aparat płciowych uzdolnień człowieka oraz na tej samej linii mieszczącego się aktu małżeńskiego. Mimo wszystko zarysowana perspektywa płciowości nie wykracza poza granice jej biologicznej rzeczywistości. A tymczasem płciowość człowieka jest płciowością istoty rozumnej i z konieczności implikuje aspekty humanistyczne. Skupiają się one w zdolności ludzkiej płciowości do wzbudzania życia ludzkiego, czyli w prokreacji. 
c) Relacja płciowości i aktu małżeńskiego do ludzkiego życia

Pojęcie prokreacji jako procesu wzbudzania ludzkiego życia stanowi kolejny człon doktryny tradycyjnej, w którym jej autentyczny sens (częściowo $\mathrm{z}$ własnej winy obrońców tej doktryny) nie został należycie odczytany przez zwalczających ją autorów, owszem został raczej gruntownie zdeformowany. Dominującym bowiem motywem ich wywodów stała się przyrodnicza konieczność procesów i działań seksualnych, warunkujących powstanie nowego życia, i na tej konieczności oparto oskarżenie koncepcji tradycyjnej o biologizm w pojmowaniu moralnych podstaw pożycia małżeńskiego. A tymczasem istotny sens doktryny tradycyjnej znajduje się na zupełnie innej płaszczyźnie.' O jaką płaszczyznę tu chodzi?

Węzłowe $w$ 'tym względzie znaczenie ma pojęcie prokreacji. Znają je wszyscy, lecz mimo to trzeba wydobyć na światło dzienne wspomniane przed chwilą zawarte $\mathrm{w}$ nim humanistyczne implikacje. Prokreacja bowiem mówi tyle, co stwarzanie nowego życia ludzkiego, które w stosunku do ludzkiej płciowości stanowi kres, czyli punkt odniesienia jej dynamicznej struktury i wynikających stąd seksualnych działań człowieka, przede wszystkim zaś aktu małżeńskiego. Mocą tego odniesienia akt małżeński oraz warunkująca go struktura płciowości całą swoją rzeczywistością zwrócone są „,ku życiu ludzkiemu” i to stale, nie tylko w mòmencie faktycznego wzbudzania tego życia, ale w sposób konstytucjonalny, mocą właściwej sobie budowyli strukturalnego ukierunkowania. W aparaturze pojęciowej filozofii tomistycznej zachodzący tu stan rzeczy określa się jako obiektywną, na samej naturze bytów opartą relację transcendentalną. Pojęcie to ma duże znaczenie dla dopełnienia i filozoficznego zinterpretowania pojęcia celowości płciowej struktury. człowieka i aktu małżeńskiego. Relacja ta bowiem zespala w specjalną (relacjonalną) jedność bytową akt małżeński z ludzkim życiem i powoduje, że akt ten uczestniczy w bytowej i moralnej godności tego właśnie życia. Dzieje się tak na zasadzie partycypacji, która zachodzi między obu członami relacji: to, co w niej ,jest odnoszone”, wznosi się na poziom doskonałości bytowej i upodabnia się do tego, „ku czemu” jest odnoszone. A więc celowość warunkująca prokreatywną sprawczość seksualnych działań człowieka ma tym’ samym udział $\mathrm{w}$ godności wzbudzanego na tej drodze życia ludzkiego i w tej perspektywie musi być zawsze rozpatrywana. Biologiczna warstwa tej celowości domaga się, aby została ogarnięta i prześwietlona przez antropologiczne ukierunkowanie, w którym dopiero znajduje swoje właściwe egzystencjalne wymiary. Już to stwierdzenie wystarczy, aby z koncepcji tradycyjnej zdjąc piętno „biologizmu” czy „fizycyzmu”, jakie się jej współcześnie tak często imputuje. Wręcz przeciwnie wykazuje ona wyraźne znamiona humanizmu, o ile na płciowość i akt małżeński patrzy się 
nie poprzez pryzmat biologicznej konieczności, ale relacyjnego odniesienia do „humanum” ludzkiego życia.

Ukazanie relacyjnych związków między aktem małżeńskim a życiem ludzkim wyznacza teren, grunt, na którym kształtuje się moralna wartość aktu małżeńskiego, ale nie ujawnia jeszcze najważniejszej warstwy konstytuujących 'tę wartość czynnilków. Przyznać też trzeba, że w dolkstrynie tradycyjnej nie zostały one należycie uwypuklone. Na tym punkcie wykazuje ona pewien niedorozwój. Poprzestawała bowiem ( w ujęciu wielu autorów, choć nie wszystkich) na sprowadzeniu życia ludzkiego do kategorii ,gatunku ludzkiego”, a więc jakby procesu mnożenia ludzkich osobników w obrębie amorficznej i ponadindywidualnej zbiorowości. Takie ustawienie sensu prokreacji osłania mgłą niedomówienia ideę godności ludzkiego życia, co utrudnia z kolei prawidłowe ustalenie moralnego sensu służącej temu życiu płciowości i małżeńskiego aktu..

d) Personalistyczny aspekt prokreacji

Konieczna jest zatem inna, personalistyczna wizja ludzkiego życia. Życie bowiem nie jest jednym z dóbr człowieka, które da się umieścić na wspólnej płaszczyźnie i porównać z innymi dobrami. W takim założeniu pozostawałaby poza życiem człowieka jakaś „,reszta” człowieka, w której dopiero realizowałaby się właściwa człowiekowi rzeczywistość i jej sens moralny. A tymczasem życie, egzystencja człowieka umieszcza się na linii jego substancjalnych doskonałości i wchodzi w skład jego podstawowych konstytutywnych elementów. Dotyka ono tego, co stanowi właściwą człowiekowi specyfikę, samo sedno człoẉieczeństwa, a przez zespolenie się $\mathrm{z}$ tym sednem $\mathrm{w}$ jeden substancjalny byt psychofizyczny stwarza realnego, pełnego człowieka. Mówiąc więc o życiu człowieka mówimy po prostu o człowieku. Konsekwentnie ujęcie celowości płciowości i aktu małżeńskiego w ich relacji do życia ludzkiego równa się uznaniu zasady, że moralny sens płciowości i aktu małżeńskiego swoją pierwszą i rołzstrzygającą przesłankę znajduje w moralnej treści człowieka.

Ten wszakże człowiek w swojej najgłębszej istocie nie jest tylko osobnikiem, jednym $\mathrm{z}$ wielu egzemplarzy gatunku ludzkiego, ale - i to przede wszystkim - jest on osobą, bytem rozumnym, obdarzonym samowiedzą i wolnością, będącym panem samego siebie, a poniekąd i otaczającego go świata. Osobowa doskonałość człowieka wyrasta z duchowego pierwiastka jego natury, staje się zaś jego udziałem z chwilą, kiedy zaczyna swe ludzkie istnienie mocą ducha uczłowieczającego ciało. Obdarzony osobową pełnią istnienia zajmuje naczelne miejsce w obrębie całego widzialnego kosmosu. Prymat pozycji człowieka we wszechświecie wyraża się przede wszystkim w tym, że z jednej strony różni się on istotowo od wszystkich innych widzialnych stworzeń, $\mathrm{z}$ drugiej zaś strony otwarty jèst całą 
szerokością swej natury na świat transcendentny i zbliża się do Boga. U podstaw chrześcijańskiej koncepcji człowieka leży jej spirytualizm i teizm.

$\mathrm{Na}$ tych powszechnie znanych sformułowaniach tyczących personalistycznego profilu człowieka wspiera się z kolei ważna dla naszego zagadnienia aksjologiczna teza etyki chrześcijańskiej. Duchowy i transcendentny wymiar natury ludzkiej stwarza bowiem grunt, na którym kształtuje się fundamentalna wartość moralna osoby. Człowiek dzięki temu, że nosi w swej naturze niezniszczalny pierwiastek ducha, którego przejawem jest jego rozumność i wolność, osiąga zdolność doskonalenia samego siebie przez dążenie do pełni własnego człowieczeństwa. Ale ta tkwiąca w nim dynamika rozwojowa kres swego dążenia znajduje na wyższym poziomie idealnego wzorca ludzkiej doskonałości jako modelu wewnętrznego ładu osoby ludzkiej, szczytowego stanu właściwej mu pełni, harmonii i dojrzałości. Podstawowe elementy tego wzorca myśl filozoficzna odczytuje w samej naturze człowieka, ale ma równocześnie świadomość, że jego ostateczny, nieskazitelny prototyp kryje się w Bogu jako źródle i prawzorze wszelkiej doskonałości.

W konkluzji stwierdzić możemy, że moralna wartość osoby ludzkiej zasadza się na bytowej doskonałości, ale ostatecznie kształtuje się na linii jej transcendentnego wymiaru. Obdarza ją ta wartość nową specyficzną godnością i sprawia, że zasługuje ona w całym przekroju swej rzeczywi-stości na szacunek i uznanie $\mathrm{z}$ racji przysługującej jej wielkości. A zyskuje tę godność przez to samo, że jest człowiekiem-osobą. Nie otrzymuje. jej ,z zewnątrz”, „od kogoś” (np. od społeczeństwa), ani „w następstwie czegoś" (np. rozwoju świadomości). Osobowa godność moralna tkwi w człowieku od samego początku, od pierwszego momentu ożywienia ciała przez pierwiastek duchowy i wyposaża ją w niezbywalne atrybuty nienaruszalności i nadrzędności w stosunku do innych wartości możliwych do realizowanía przez człowieka w toku jego świadomej działalności. Tú też kryje się źródło, z którego biorą początek moralne postulaty określające warunki niezbędne dla godnego osoby ludzkiej rozwoju (np. instytucja małżeństwa i rodziny). Także u podstaw innych szczegółowych wartości moralnych leży odniesienie ich do doskonałości osoby, którą mają rozwijać i pomnażać, doskonałość zaś osoby stanowi cel cenny dzięki własnej godności i niczemu (w porządku dóbr przygodnych) nie podporządkowany.

\section{OKRESLENIE MORALNEJ WARTOSCI AKTU MAEŻEŃSKIEGO}

1. Podstawowe kryteria moralnej wartości aktu małżeńskiego

Wróćmy wszakże do zasadniczego tematu, w którym chodzi o ustalenie istotnych czynników określających moralną wartość aktu małżeńskie- 
go. Opierając się na tej przesłance będzie można rozstrzygnąć problem moralnej wartości tegoż aktu w warunkach okresowej bezpłodności.

Obiektywistyczna orientacja etyki tradycyjnej kazała w analizie aktu małżeńskiego zwrócić najpierw uwagę na rolę fundamentalnej relacji, mocą której akt małżeński zwrócony jest ku ludzkiemu życiu." Później stało się wiadome, że życie to ma charakter osobowy, powiedzmy lepiej, utożsamia się z osobą ludzką, którą w tym wypadku jest ,ta trzecia osoba" powoływana do życia aktywnym współudziałem małżonków. Zachodżąca między nimi koniunkcja sprawia, że akt małżeński czerpie swój podstawowy sens moralny z moralnej wartości i godności ,tej trzeciej osoby”, która znajduje się na horyzoncie właściwej mu celowości. Dodać zaś trzeba, że relacjonalna więź aktu małżeńskiego $\mathrm{z}$ osobowym życiem ludzkim zadzierżga się nie w odniesieniu do ogółu pożycia małżeńskiego czy jego fundamentalnej intencji, ale między tym życiem i każdym z osobna wziętym aktem małżeńskim. Każdy $\mathrm{z}$ nich bowiem nosi $\mathrm{w}$ sobie zdolność i ukierunkowanie do wzbudzenia życia ludzkiej odrębnej osoby i tym samym staje się podmiotem całej z tym życiem związanej moralnej wielkości. Z drugiej strony relacjonalne powiązanie aktu małżeńskiego $\mathrm{z}$ indywidualnie wziętym osobowym życiem ludzkim nie stoi na przeszkodzie, że występuje on w kontekście innych jeszcze wartości życia małżeńskiego, przede wszystkim własnych podmiotowych wartości małżonków, których urzeczywistnieniu $\mathrm{w}$ odpowiednich granicach służy.

I tak życiotwórcze, na zrodzenie ludzkiej osoby nastawione przeznaczenie aktu małżeńskiego wyciska swe piętno na moralnej treści i ukierunkowaniu miłości małżeńskiej. Najgłębszy sens tej miłości polega na uznaniu i'szacunku dla ludzkiej godności wybranej osoby seksualnie atrakcyjnej i zdeterminowanej biopsychicznie do wzbudzania ludzkiego życia. Miłość małżeńska nie kształtuje się przeto w sferze odizolowanej od elementów określających moralną wartość aktu małżeńskiego. Pozostają one w ścisłym ze sobą związku i zależności. Rzecz wymagałaby osobnego rozwinięcia i uzasadnienia. Chwilowo trzeba jednak poprzestać na wytyczeniu kierunku przyporządkowania, jakie między nimi zachodzi. Uprzedniość i obiektywny charakter moralnego statusu płciowości i jej funkcjonowania sprawia, że miłość małżeńska implikuje w swej aksjologicznej treści szacunek i akcep̉tację etycznej zawartości aktu małżeńskiego. Wyposażona $\mathrm{w}$ ten sposób $\mathrm{w}$ moralne treści rodzicielstwa ștaje się ważnym współczynnikiem ludzkich wymiarów aktu małżeńskiego, wzbogacając go równocześnie o szeroką gamę własnych swoich wartości i duchowych przeżyć.

Moralny sens płciowości i aktu małżeńskiego oparty na rządzącej nimi, „ku trzeciej osobie” zorientowanej celowości, stanowi również kryterium, według którego należy ustalać etyczne granice doznań przyjemnoś- 
ciowy.ch związanych $\mathrm{z}$ seksualną aktywnością człowieka, a także innych dóbr pożycia małżeńskiego. Zasługują one wszystkie na akceptację i muszą być uznane za integralne składniki etycznych wartości małżeństwa, byle funkcjonowały $\mathrm{w}$ zgodzie $\mathrm{z}$ fundamentalnymi prawami moralności małżeńskiej wypisanymi w moralnej strukturze płciowości i alktu małżeńskiego.

\section{Moralny imperatyw uszanowania struktury aktu małżeńskiego}

Te. trzy zasadnicze kryteria moralnej wartości aktu małżeńskiego, z których jeden określa jego wewnętrzną zawartość, dwa pozostałe tyczą stosunku aktu małżeńskiego do towarzyszących mu dóbr i celów życia małżeńskiego, stwarzają z kolei normatywne przesłanki do sformułowania odpowiednich reguł postępowania. Pominiemy w tym zestawie podstawowy dla etyki seksualnej moralny postulat, mocą którego akt seksualny dokonywać się może tylko i wyłącznie w ramach prawowitej wspólnoty małżeńskiej. Zakładając tedy etycznie „małżeński” charakter aktu małżeńskiego na czoło wysunąć należy moralny nakaz uszanowania integralnej struktury płciowości i alktu małżeńskiego oraz działania zgodnego $\mathrm{z}$ ich wewnętrzną prawidłowością. Podstawę aksjologicznej treści oraz imperatywnej mocy tego nakazu stanowi nadrzędny i nienaruszalny charakter potencjalnego życia (,țrzeciej osoby"), do wzbudzenia którego zmierza celowość aktu małżeńskiego. Także zasięg tego nakazu właściwą sobie miarę znajduje w moralnym stalusie życia ludzkiego, na którym skupia się dynamiczna-rzeczywistość aktu małżeńskiego. Jak to życie nie zawiera w sobie ograniczeń wynikających $\mathrm{z}$ podporządkowania go takim czy innym celom samych małżonków względnie społeczeństwa (miłość, trwałość wspólnoty, względy demograficzne), ale nad nimi góruje i podporządkowuje je sobie, to znaczy własnej godności moralnej, tak samo moralna wartość aktu małżeńskiego rozciąga się na każdy z osobna akt małżeński spełniany świadomie przez odpowiedzialnych za swe czyny małżonków. Innymi słowy moralny iınperatyw uszanowania integralnej struk-tury płciowości i aktu małżeńskiego ma charakter normy stałej i absolutnej, czyli niedopuszczającej sytuacyjnie uwarunkowanych wyjątków.

\section{Moralne zło antykoncepcji}

$\mathrm{Na}$ podstawie ustalonej reguły moralnej można wyprowadzić dwa interesujące nas wnioski normatywne. Pierwszy z nich dotyczy pożycia seksualnego małżonków, w którym stosują oni (za obopólną zgodą lub we własnym imieniu jednego z partnerów) środki zmierzające wprost do unicestwienia prokreatywnej skuteczności tego pożycia, innymi słowy stosują powszechnie znaną antykoncepcję. W tym bowiem przypadku małżonkowie $\mathrm{z}$ całości aktu małżeńskiego wybierają świadomie jedynie do- 
znania przyjemnościowe, względnie osobiste cele małżeńskie, natomiast przyporządkowanie tego alktu do wzbudzania życia ,trzeciej osoby" celowo przekreślają i udaremniają. Takim działaniem - na linii i w granicach jego relacyjnego, ale realnego odniesienia go do owego życia godzą w moralne atrybuty życia ludzkiego, przede wszystkim w jego nadrzędność i nienaruszalność. A to jest ingerencja niezgodna z moralnym charakterem aktu małżeńskiego, uniemożliwia mu ona urzeczywistnienie właściwego mu przeznaczenia moralnego, co sprawia, że staje się działaniem moralnie złym. Nie może być wówczas mowy o twórczej moralnie afirmacji miłości małżeńskiej, czy też realizacji innych dóbr życia małżeńskiego. Z wysokości moralnych celów spadają one na poziom ,,interesów" małżeńskich o wartości czysto utylitarnej czy hedonistycznej.

4. Moralna kwalifikacja bezpłodnych aktów małżeńskich

$\mathrm{Na}$ tle moralnego potępienia antykoncepcji można na koniec spełnić właściwe zadanie niniejszego studium i naświetlić moralny sens pożycia małżeńskiego w okresach biologicznej bezpłodności żony, czy „,bezpłodnych aktów małżeńskich". Zacząc wypada od przypomnienia i ponownego podkreślenia wypunktowanej uprzednio idei integralnego pojmowania biologicznej struktury i funkcji płciowości jako „oddolnego” czynnika ich celowości. Stwierdzono mianowicie, że w skład tej struktury wchodzą w jednakowym stopniu elementy determinujące płodność, jak też niepłodność aktu małżeńskiego, spiętych jakby klamrą wspólnym odniesieniem do nadrzędnej racji życia ,trzeciej osoby”. Ten stan rzeczy konstytuuje oibiekitywny kształt i prawidłowość funkcjonowania aktu małżeńskiego, a także wyznacza czynniki określające przysługującą temu aktowi wartość moralną. Rozciaga się ona na całość spełnianych w tym zalkresie aktów małżeńskich, a więc obejmuje swoim zasięgiem zarówno płodne jak i niepłodne akty. Takie też aksty spełniają małżonkowie, którzy nie stcsują żadnej z metod regulacji poczęć i niepodobna twierdzić, że kiedy współżyją w dniach bezpłodnych podejmują mniej moralnie wartościowe akty małżeńskie, aniżeli kiedy czynią to w okresie płodności. A gdyby się tak złożyło (założenie praktycznie mało prawdopodobne, ale teoretycznie przydatne), że przypadkiem, bez specjalnego zamysłu, ale stale szukaliby zbliżenia w okresach bezpłodności, również nie byłoby podstaw do zarzucania im niedoskonałego (choćby tylko z obiektywnego punktu widzenia, niezależnie od subiektywnej odpowiedzialności) współżycia małżeńskiego.

Problem moralny zaczyna się więc dopiero z chwilą, kiedy bierze się pod uwagę sytuacje świadomego i c eloweg o pod kątem unikni ęc i a z a pło d n i en i a podejmowania aktów máłżeńskich w dniach biologicznej bezpłodności. Występuje tu niewątpliwie czynnik manipulacji ze strony małżonków w zakresie pożycia seksualnego. Może więc po- 
wstać podejrzenie, że dzieje się to z naruszeniem moralnej celowości i właściwego sensu aktu małżeńskiego. Odpowiedź nie da się jednak sformułować w jednym zdaniu ze względu na dwa bieguny tkwiącej w bezpłodnym akcie małżeńskim rzeczywistości moralnej. Trzeba zatem rozpatrzyć rzecz z dwojakiego punktu widzenia.

Pierwszy z nich dotyczy obiektywnego statusu moralnego bezpłodnych aktów małżeńskich. Jak wspomniano, mieszczą się one całkowicie w granicach właściwej tym aktom celowości i z tego powodu uczestniczą w ich fundamentalnej godziwości moralnej. Dobieranie czasu bezpłodnego współżycia małżen̂skiego stanowi $\mathrm{w}$ porównaniu $\mathrm{z}$ wewnętrzną osnową aktu okoliczność zewnętrzną, nie docierającą do jego moralnej głębi i nie naruszającą jego moralnej prawidłowości. Na tym odcinku zachodzi zasadnicza różnica między aktem antykoncepcyjnym a aktem bezpłodnym. W pierwszym człowiek ingeruje w wewnętrzną celowość aktu małżeńskiego i tym samym godzi w określającą jej moralną treść nienaruszalność osobowego życia ludzkiego. W akcie bezpłodnym całość jego przebiegu dokonuje się po linii rządzącej nim prawidłowości. Toteż nie występuje w nim ingerencja przeciwko tkwiącemu w nim odniesieniu do potencjalnego życia „trzeciej osoby”. W tym założeniu nawet swoją beżpłodnością pozostaje on w wymaganej relacji szacunku i afirmacji życia tej osoby.

Jednakowoż w małżeńskim akcie bezpłodnym obok jego obiektywnej struktury moralnej występują jeszcze cele, w imię których małżonkowie decydują się na wykorzystywanie biologicznego okresu bezpłodności, aby uniknąc $\mathrm{w}$ ten sposób potomstwa. I tu dopiero sprawa zaczyna się komplikować. Jeżeli bowiem te cele mają na oku przede wszystkim maksymalizację doznan przyjemnościowych albo życiowego komfortu czy innych utylitarnych wartości za cenę uniknięcia ciężarów rodzicielstwa, do którego małżonkowie poza tym są zdolnị; nie ulega wątpliwości, że w tej warstwie czynników moralnej wartości beźpłodnego aktu małżeńskiego nie spełnia on wymogów całościowo wziętej moralności i staje się aktem moralnie złym i nagannym. Wspomniane cele poza ramami rozpatrywanego aktu mogą mieć swoje etyczne uzasadnienie. Ale w momencie, kiedy stają się dominującym motywem postępowania i podporządkowują sobie cele prokreatywne, zatracają sens moralny. Służą już nie osobowemu życiu ludzkiemu zawartemu w prokreacji, ale wartościom niższym w stosunku do życia ludzkiego instrumentalnym. Ma tu miejsce rzeczywista manipulacja wartościami humanistyıcznymi na rzecz indywidualnej wygody czy życiowego użycia.

Zmienia się obraz moralnej wartości bezpłodnego aktu małżeńskiego dopiero z chwilą, kiedy miejsce celów hedonistycznych czy utylitarnych zajmują cele równorzędne do moralnego sensu prokreacji. Za takie zaś cele należy uznać bądź osobowe dobra małżonków (np. stan zdrowia), albo 
równie osobowe dobro dzieci już poczętych albo też planowanych. Idzie tu przede wszystkim o sytuację, w których ograniczenie liczby potomstwa podyktowane jest troską o zabezpieczenie czy stworzenie w rodzinie odpowiednich warunków rozwojowych i wychowawczych. Wtedy wszystkie elementy moralnej wartości bezpłodnego aktu małżeńskiego utrzymane są na tym samym poziomie dóbr osobowych, aktywność zaś małżonków polega ostatecznie na ustalaniu porządku i warunków ich realizacji.

Nawiasem można jeszcze wspomnieć, że bezpłodnemu pożyciu małżeńskiemu $\mathrm{w}$ usprawiedliwionych moralnie sytuacjach towarzyszy jeszcze wiele innych zalet moralnych: urzeczywistnia ono i afirmuje moralny sens miłości małżeńskiej, wyzwala świadome dążenie do samoopanowania i dyscypliny, uzdalnia człowieka do ponoszenia ofiar. W takich warunkach bezpłodny akt małżeński okazuje się zarówno w swej podstawowej obiektywnej osnowie jak i w elementach wtórnych, najczęściej. w realizowanych doraźnie przez małżonków celach i potrzebach ich małźeńskiego życia, wolny od moralnego nieładu, a więc godziwy, wartościowy. Trudno tu już mówić o „manipulacji”: jest to działnie rozumne, odpowiedzialne, etycznie uzasadnione.

\section{WNIOSKI}

W zakończeniu niniejszego studium spróbujmy raz jeszcze ogarnąc całość dotychczasowych rozważan, aby wydobyć z nich to, co się wydaje najbardziej charakterystyczne dla toczących się na interesujący nas temat dyskusji.

Do rozpatrzenia postawiony został dosyć zawężony problem: czy pożycie maiżeńskie w okresie biologicznej bezpłodności można uznać za usprawiedliwiony moralnie środek regulacji poczęć. Okazało się wszakże, że problem ten stanowi tylko swego rodzaju wycinek obszerniejszego i bardziej skomplikowanego problemu, w którym chodzi znowu o moralny osąd działań antykoncepcyjnych $\mathrm{w}$ ich wielorakich formach. Wstępne rozeznanie w świecie współczesnej fillozofii moralności ujawniło, że w tej sprawie konkurują ze sobą dwa rozwiązania, z których jedno aprobuje antykoncepcję jako moralnie dopuszczalną, drugie zaś ją potępia jako moralnie złą i naganną. Obydwie wszakże koncepcje opierają się na dwu przeciwstawnych sobie filozoficzno-etycznych podstawach, czego dalszą konsekwencją było ustalenie, że ostatecznie chodzi tu o spór dwu wielkich systemów filozoficzno-etycznych: relatywizmu $\mathrm{z}$ jednej strony, a z drugiej zaś etyki obiektywnej i absolutnej.

Jest to, jak się zdaje, w omawianej sprawie fakt ogromnej doniosłości, który rzutuje w zasadniczy sposób na filozoficzno-etyczną tożsamość ścierających się ze sobą stanowisk i poglądów. Przede wszystkim pozwala on 
spojrzeć krytycznie na głoszone w kontekście naszego zagadnienia hasła, które z pierwszym stanowiskiem wiążą afirmację postępu, rozumu i wolności jako przeciwwagę dla sztywnego konserwatyzmu, dogmatyzmu i rygoryzmu drugiego poglądu. U końca przeprowadzonych analiz można spokojnie stwierdzić, że chodzi tu po prostu o ścieranie się dwu odmiennych tendencji filozoficzno-etycznych. $\mathrm{Z}$ tych jedna importowana jest $\mathrm{z}$ zewnątrz, z naturalistyczno-relatywistycznych nurtów najczęściej anglosaskich szkół filozoficznych, druga zaś jest kontynuacją odwiecznej tradycji filozofii chrześcijańskiej. Tam zaś, gdzie walczą ze sobą „dwie filozofie”, „rozum” jest po obu stronach, rozstrzygnięcie zaś po której stronie ten rozum jest czynnikiem postępu i wyzwolenia gdzie zaś zacofania i skrępowania myśli, zależy od tego, po której stronie jest prawda. Ona jest najwyższym kryterium rozstrzygającym wszelkie spory naukowe, w tym także filozoficzno-etyczne. Jej przeto należy przyznać prymat w badaniach i dyskusjach filozoficznych, "ograniczyć zaś do minimum rolę emocji, uprzedzeń i pozadoktrynalnych tendencji.

Nie ulega wątpliwości, że walnym środkiem dochodzenia do prawdy jest dyskusja. Toteż powstawanie odmiennych, czy nawet wręcz antagonistycznych stanowisk, jak również ścieranie się alternatywnych rozwiązań z filozoficznego punktu widzenia należy uważać za zjawisko nie tylko zupełnie zrozumiałe, ale i twórcze. Aby jednak w sytuacji pluralistycznych rozwiązań mogły być osiągnięte pożądane wyniki, jest rzeczą niezbędną przestrzeganie fundamentalnego postulatu rzetelności nạkowej, domagającej się rozpoznania autentycznej myśli przeciwnej strony. Tylko pod tym (między innymi) warunkiem dyskusja może być dialogiem, $\mathrm{w}$ przeciwnym razie staje się konfrontacją a nawet demagogiczną licytacją.

Ottóż uderza drugi stwierdzony przez nas fakt, że w dyskusji nad moralnością anty- czy prokoncepcji w nader wielu wypowiedziach występuje zdeformowany obraz tradycyjnej doktryny etycznej. Można oczywiście postawić sobie pytanie, jak to się stało, że tradycyjna, głęboko z rozwojem chrześcijańskiej kultury duchowej związana doktryna filozoficzna jest tak gruntownie przez samych katolików zapoznawana lub przeinaczana. Nie próbując jednak tego problemu rozwiązywać, trzeba poprzestać na stwierdzeniu, że w tej sytuacji, aby dyskusję umieścić na właściwej platformie, pierwszym zadaniem do spełnienia jest rekonstrukcja autentycznego i w miarę możności pełnego obrazu tej doktryny, ukazanie, co w niej zostało zapoznane względnie przeinaczone, co zajmuje dominującą pozycję, co zaś należy przesunąć na dalszy plan. Doktryna tradycyjna nie jest teorią pod każdym względem należycie wypracowaną, nie wymagającą korektur i rozbudowy. Ale pierwszym warunkiem rzeczowej z nią dyskusji jest widzieć ją taką, jaką jest, nie zaś taką, jaką chce się ją widzieć, 
aby z większą łatwością móc ją skrytykować czy odrzucić, Odrzuca się bowiem wtedy nie atakowaną doktrynę, ale przez siebie samego narysowaną jej karykaturę.

Dokonane przez nas zabiegi miały na celu przedstawienie doktryny tradycyjnej w bardziej obiektywny sposób. Ale już próbny zarys tej doktryny pozwala uwolnić ją od sypiących się na nią zarzutów i pokazać, że nie ma w niej miejsca na kult biologii i determinizmu fizjologicznych praw płciowych. Wręcz odwrotnie naczelną ideą przenikającą swą treścią głoszone przez tę etykę nakazy i zakazy jest kult ludzkiego życia, moralnej godności i wielkości tej „trzeciej osoby”, ku której płciowość i akt małżeński zwrócone są całą swą aksjologiczną treścią. W kręgu tego kultu mieści się zarówno negacja antykoncepcji, jak też aprobata (zakładając wymagane warunki) pożycia małżeńskiego w okresie bezpłodności. One też wyznaczają drogi moralnego rozwoju człowieka, wskazania prawego rozumu i aktualizację twórczej wolności.

Zrekonstruowana filozoficzno-etyczna koncepcja etycznej regulacji poczęć przyjmowana przez tradycyjną etykę chrześcijańską (przede wszystkim w wersji tomistycznej) pozostaje w zasadniczej zgodzie co do treści podstawowych norm z nauką Pawła VI w enc. Humanae vitae i całego Kościoła. Niemniej jednak z nią się nie utożsamia. Nauczanie papieży i Kościoła, (Magisterium Ecclesiae) umieszcza się bowiem na innej płaszczyźnie doktrynallnej i nie może być stawiane na rólwni $\mathrm{z}$ żadnym systemem filozoficzno-etycznym. Można się co najwyżej zastanowić nad tym, który z wypracowanych systemów nadaje się lepiej do interpretacji nauki papieży i Kościoła względnie od którego z nich papieże zapożyczają pewne pojęcia czy tezy dla wyrażenia własnej doktryny. Z tego punktu widzenia relatywizm etyczny stanowi świat idei obcy intelektualnemu klimatowi nauczania papieskiego.

W świetle dokonanej analizy okazuje się ponadto, że nie nadaje się on również do przeprowadzenia konstruktywnej interpretacji teologicznej tegoż nauczania.

LES NORMES MORALES DE LA REGULATION DES NAISSANCES

Rés u mé

Les protestations soulevées par l'encyclique Humanae Vitae n'avaient pas seulement comme cause la condamnation par Paul VI de l'utilisation des contraceptifs, mais aussi la position de l'Eglise en faveur des méthodes naturelles, c'est-à-dire, pour parler concrètement, des relations sexuelles durant la période d'infertilité de la femme. Si Paul VI rejetait la contraception en tant que pratique coupable, il approuvait par contre l'abstinence périodique. 
Parmi les diverses raisons alléguées contre l'enseignement du Pape, trois retiennent l'attention:

$1^{\circ}$. Conformément à l'enseignement traditionnel fondamental, la valeur morale de l'acte sexuel lui est assignée par son orientation, autrement dit, par son "ouverture" sur la procréation. Dans le cas des relations de la période d'infertilité, fait défaut cette orientation de l'acte vers la procréation, d'où le mal qu'il comporte.

$2^{\circ}$ De même, 1 intention des époux d'avoir des relations durant les jours d'infertilité renvoie directement à la non-fécondité de ces relations. Dans ce but, les époux fixent la période des relations sexuelles aux jours infertiles pour éviter une grossesse éventuelle. Mais cela signifie une intention causative de l'acte malgré sa destination à la création, et non seulement une permission, une tolérance.

$3^{\circ}$. Le troisième argument des opposants et le plus important, à l'enselignement du Pape, tend à prouver que les fondements biologiques et métaphysiques de sa doctrine sont anti-scientifiques. Celui-ci se base sur l'idée de sacralisation des structures biologiques de la sexualité humaine et de leur inviolabilité. Un tel principe comporte pourtant un passage injustifié du déterminisme absolu des lois biologiques à des lois morales obligeant en conscience, la reconnaissance de la primauté de la nature sur la raison et du déterminisme biologique sur la liberté.

La contestation suscitée contre l'enseignement du Pape découle principalement des sources philosophiques: elle se sert d'une argumentation de type philosophique dont l'un des composants est une interprétation de la doctrine traditionnelle de la morale et de la théologie catholique: c'est sous cet aspect qu'a été conçu le présent article. Son propos est d'éclairer les éléments philosophiques de la problêmatique morale sur la régulation des naissances, en prenant en considération l'ídée que se font les contestataires de la doctrine traditionnelle.

Une réflexion d'ordre philosophique et moral sur les problèmes soulevés amène tout d'abord a constater qu'a la base du rejet des méthodes naturelles de régulation des naissances et en' relation avec ce sujet, de l'adhésion à la contraception, résident cachés, mais faciles à identifier, les principes relativistes des tenants de cette attitude. Ces principes se manifestent dans le rejet des facteurs permanents et inhérents à la structure de l'acte sexuel qui définissent la valeur morale de cet acte. Dans cette conception, on fait dépendre la moralité de l'acte des facteurs externes, tels que les buts subjectifs, les résultats obtenus ou encore le principe d'un compromis moral et le choix du moindre mal. Basées sur ces principes, les normes de conduite ont un caractère relatif, qui admet les dérogations dépendant des situations vécues, et l'abandon d'une règle obligatoire en général.

Dans le monde de la phìlosophie; le relativisme moral a cependant son adversaire et en même temps sa contre-proposition philosophique, qui est l'éthique chrétiēnne objective et absolue. La thèsè principale de celle-ci est l'affirmation que l'acte humain en lui-même c'est-à-dire dans le fond de son propre dynamisme, contient les facteurs fondamentaux qui lui confèrent son propre contenu moral, Ces facteurs s'identifient avec le principe fondamental structurel qui caractérise la finalité de l'acte. La finalité consiste à orienter l'acte vers l'obtention d'un résultat approprié constituant le facteur premier et dédisif pour définir la spéclifité interne de cet acte. Ce résultat s'appele „objet de l'acte”, „sa matière”, ou encore le „but de l'acte". L'objet de l'acte en tant qu'élément structurel permanent et immuable de l'acte, conçu dans sa relation avec sa valeur morale propre, permet de bâtir les normes d'un caractère également permanent et absolu c'est-à-dire n'admettant pas - dans le cas d'un acte conditionné par l'objet, ou „intérieurement" mauvais 
des exceptions conditionnées par la situation, et des négations d'unè règle qui oblige en conscience.

Diamétralement opı osés dans leur définition, les points de départ de l'éthique relativiste et de l'éthique absolue désignent d'une manière fondamentale des décisions particulières dans le cadre des aspects moraux de la régulation des naissances. L'acent mis sur le ròle de la finalité interne de l'acte dans la constitution de sa valeur morale ne permet pas au caractère ouvert de l'acte sexuel de s'indentifier avec l'effet procréateur de cet acte, comme l'indentifient certains moralistes. L'essence de cette ouverture se fonde sur l'ordonnance interne et l'organisation de l'acte sexuel. Si cet acte se réalise conformément à sa finalité, il demeure lui-même un acte „ouvert" sur la procréation, aussi bien lorsqu'il atteint le résultat voulu que lorsqu'il ne l'atteint pas, en un mot, qui'l soit suivi ou non d'une grossesse.

L'analyse ultérieure de la finalité interne de l'acte conjugal montre la nécessité d'assumer intégralement cette finalité. La plénitude de sa réalité comprend également des processus déterminant la fécondité biologique de l'acte sexuel ainsi que des éléments et des processus conditionnant son infertilité. Ce sont les deux composantes intégrales déterminant la finalité procréatrice de l'acte sexuel.

La finalité procréatrice de l'acte sexuel possède en définitive un caractère éminemment relationnel. Ce caractère réside avant tout dans le fait que l'acte sexuel est orienté vers une troisième vie personnelle dont il sert l'éveil. Par conséquent, au service d'une vie humaine naissante, il participe à la dignité existentielle et morale de cette vie. L'élément biologique de la finalité de l'acte sexuel est compris et éclairé par sa relation anthropologique. Dans cette vie humaine également personnelle qui se trouve pour ainsi dire à l'horizon de la finalité de l'acte sexuel, réside le mystère de sa vulnérabilité, et en même temps se situe la source des postulats moraux particuliers et non pas dans les déterminismes biologiques de la sexualité humaine.

Les postulats les plus importants une fois examinés, l'objet de nos réflexions séra le mal moral de la contraception. Le sens essentiel de ce mal consiste en ce que les moyens anti-conceptionnels, en raison même de leur finalité propre, éliminent et déjouent l'ordre de l'acte sexuel, qui est soumis à l'éveil de la vie d'une nouvelle personne. Par lă, à la limite et dans les frontières de son rapport relationnel réél avec cette vie, sa supériorité et son inviolabilité la plaçant plus haut que les buts hédonistes ou utilitaires, tendent vers les attributs moraux de cette vie.

A la lumière des prémisses exposés, il ressort une différence fondamentale entre le coté moral de la vie sexuelle des époux durant lés jours d'infertilité et le mal moral de la contraception. On a constaté que dans la composition de la finalité procréatrice de l'acte sexuel, entrent au même degré des éléments déterminant la fécondité ou l'infertilité de l'acte sexuel. Leur conception globale et le lien qui les unit pour ainsi dire, est la relation commune à une raison de vie d'une troisième personne. Cet état objectif des choses fait que les relations durant des jours d'infertilité se situent dé la même manière dans le cadre de la finalité propre à cette vie, aussi bien lorsque les relations sexuelles sont sciemment décidées en tenant compté de la régulation des naissances justifiée par des motifs graves. Des motifs égoistes dictant ce choix pourraient susciter des réserves, mais le mal causé par l'attitude des époux a alors son origine dans la sphère des motivations de cette attitude, et non pas dans sa structure objective. Les buts subjectifs immoraux déforment dans ce cas la globalité de l'activité sexuelle, en dépit d'une justification fondamentale de sa structure objective.

Dans les remarques par lesquelles nous concluons, encore une fois, nous sou- 
lignons, que l'enseignement de l'Eglise sur la régulation des naissances constitue aujourd'hui l'occasion et le terrain d'une confrontation entre deux systèmes philosophiques et moraux: le relativisme éthique d'une part et de l'autre, l'éthique absolue et objective. Des valeurs des raisons et arguments invoqués dépendent des critères qui permettent de dire lequel de ces systèmes consititue le postulat de la raison et du progrès. Le relativisme en morale est un courant philosophique et moral important, qui s'est développé sans diścontinuité depuis quatre siècles dans l'histoire de la pensée éthique européenne. Mais soumis à la critique philosophique, il apparait comme un système inadéquat et erroné quant à ses principes de base. La discussion sur le problème éthique de la régulation des naissances est une confirmation supplémentaire de ce point de vue. D'autant plus que ce n'est pas un système dont la position pourrait mettre en pratique une-négation aussi radicale de l'enseignement de l'Eglise. 